University of Nebraska - Lincoln

DigitalCommons@University of Nebraska - Lincoln

\title{
SELECTIVE AND ORGANOTYPIC CULTURE OF INTRAHEPATIC BILE DUCT CELLS FROM ADULT PIG LIVER
}

Neil C. Talbot

USDA, ARS

Thomas J. Caperna

USDA, ARS

Follow this and additional works at: https://digitalcommons.unl.edu/usdaarsfacpub

Part of the Agricultural Science Commons

Talbot, Neil C. and Caperna, Thomas J., "SELECTIVE AND ORGANOTYPIC CULTURE OF INTRAHEPATIC BILE DUCT CELLS FROM ADULT PIG LIVER" (1998). Publications from USDA-ARS / UNL Faculty. 689. https://digitalcommons.unl.edu/usdaarsfacpub/689

This Article is brought to you for free and open access by the U.S. Department of Agriculture: Agricultural Research Service, Lincoln, Nebraska at DigitalCommons@University of Nebraska - Lincoln. It has been accepted for inclusion in Publications from USDA-ARS / UNL Faculty by an authorized administrator of DigitalCommons@University of Nebraska - Lincoln. 


\title{
SELECTIVE AND ORGANOTYPIC CULTURE OF INTRAHEPATIC BILE DUCT CELLS FROM ADULT PIG LIVER
}

\author{
NEIL C. TALBOT ${ }^{1}$ AND THOMAS J. CAPERNA \\ USDA, ARS, LPSI, Gene Evaluation and Mapping Laboratory, Beltsville Agricultural Research Center, Building 200, Room 13, Beltsville, \\ Maryland 20705 (N. C. T.), and USDA, ARS, LPSI, Growth Biology Laboratory, Beltsville Agricultural Research Center, Building 200, \\ Room 202, Beltsville, Maryland 20705 (T. J. C.)
}

(Received 22 October 1997; accepted 9 July 1998)

\begin{abstract}
SUMmARY
Secondary culture of nontransformed bile duct epithelium has been difficult to achieve. STO feeder cell-dependent secondary cultures of adult pig bile duct cells were established from primary cultures of adult pig liver cells. Adult pig hepatocytes exhibited limited or no replication and were lost from the secondary culture at Passage 3 or 4 . In contrast, adult pig bile duct cells replicated and were carried for 4-8 passages in secondary culture. A simple method to produce nearly pure pig intrahepatic bile duct cultures was first to freeze a relatively crude liver cell preparation. Upon subsequent thawing, all hepatocytes and most macrophages were lysed. Bile duct cells composed $95 \%$ of the surviving cells after the freeze/thaw, and they grew out rapidly. The bile duct cells grew on top of the STO feeder cells as closely knit epithelial, colonial outgrowths. Histocytochemical and biochemical analyses demonstrated high levels of gamma-glutamyltranspeptidase activity and low levels of P450 activity in the bile duct cultures. The bile duct cells spontaneously adopted a multicellular ductal morphology after 7-10 d in static culture which was similar to that found in in vivo pig liver. Transmission electron microscopic examination revealed complex junctions and desmosomes typical of epithelium, and lumenally projecting cilia typical of in vivo intrahepatic bile ductules. This simple method for the coculture of pig intrahepatic bile duct cells which adopt in vivo-like structure may facilitate biological studies of this important, but difficult to culture, cell type.
\end{abstract}

Key words: cell; culture; bile duct; liver.

\section{INTRODUCTION}

The isolation and continuous culture of normal adult intrahepatic bile duct cells has been difficult to achieve. In vitro models that closely mimic in vivo liver intraheptic bile ductules are needed for studies of bile duct epithelium (BDE) cell differentiation and function (reviewed in Sirica, 1992; Van Eyken and Desmet, 1993).

Several methods have been reported for the isolation and primary culture of bile duct epithelial cells or intact ductules (Van Eyken and Desmet, 1993; reviewed in Alpini et al., 1994). Isolation and purification of intrahepatic bile duct cells is technically challenging because they comprise less than $5 \%$ of the liver cell population (Yokoyama et al., 1953; Daoust and Cantero, 1959; Ishii et al., 1989). The bulk of the liver is made up of hepatocytes $(60 \%)$ and various mesenchymal cells $(35 \%)$ such as macrophages, endothelial cells, and fibroblasts (Yokoyama et al., 1953; Daoust and Cantero, 1959). Some of these cells can range to a size and density similar to that of BDE cells (Ishii et al., 1989). Isolation of BDE cells generally included an enzymatic and calcium chelator perfusion of the liver followed by physical disruption as used in the current methods of hepatocyte isolation. Multistep centrifugational and immunoaffinity methods for the enrichment of bile ductules or individual cells were then applied (Grant and Billing, 1977; Sirica and Cihla, 1984; Ishii

${ }^{1}$ To whom correspondence should be addressed. et al., 1989; Joplin et al., 1989; Yang et al., 1993; Okamoto et al., 1995). The resulting primary cultures were sometimes highly enriched for BDE, and exhibited BDE-specific functions for wk or mo. depending on the growth factor and matrix supports used (Sirica et al., 1985; Demetris et al., 1988; Joplin et al., 1989; Mathis and Sirica, 1990).

The secondary culture or development of cell lines of BDE are recent accomplishments. Viral oncogene-immortalized BDE cell lines of the human were reported (Grubman et al., 1994; Perrone et al., 1995). Joplin et al. (1992) demonstrated the serial propagation of normal human BDE in response to hepatocyte growth factor (HGF). Most recently, a continuous culture of normal rat BDE was established with collagen matrix that maintained BDE characteristics over 70 passages and 22 mo. in culture (Vroman and LaRusso, 1996). The cells formed polarized monolayers on collagen-coated transwell inserts with demonstrated transepithelial resistance and distinct basolateral vs. apical physiological responsiveness (Vroman and LaRusso, 1996).

We have previously demonstrated that STO feeder cells will support the differentiation and growth of pig epiblast-derived, liver stem cell-like cells (Talbot et al., 1994a, 1996). We have also shown that STO feeder cells will support the growth of pig fetal liver cells that differentiated into hepatocytes and ductal structures (Talbot et al., 1994b). We now show that adult pig intrahepatic bile duct cells can 

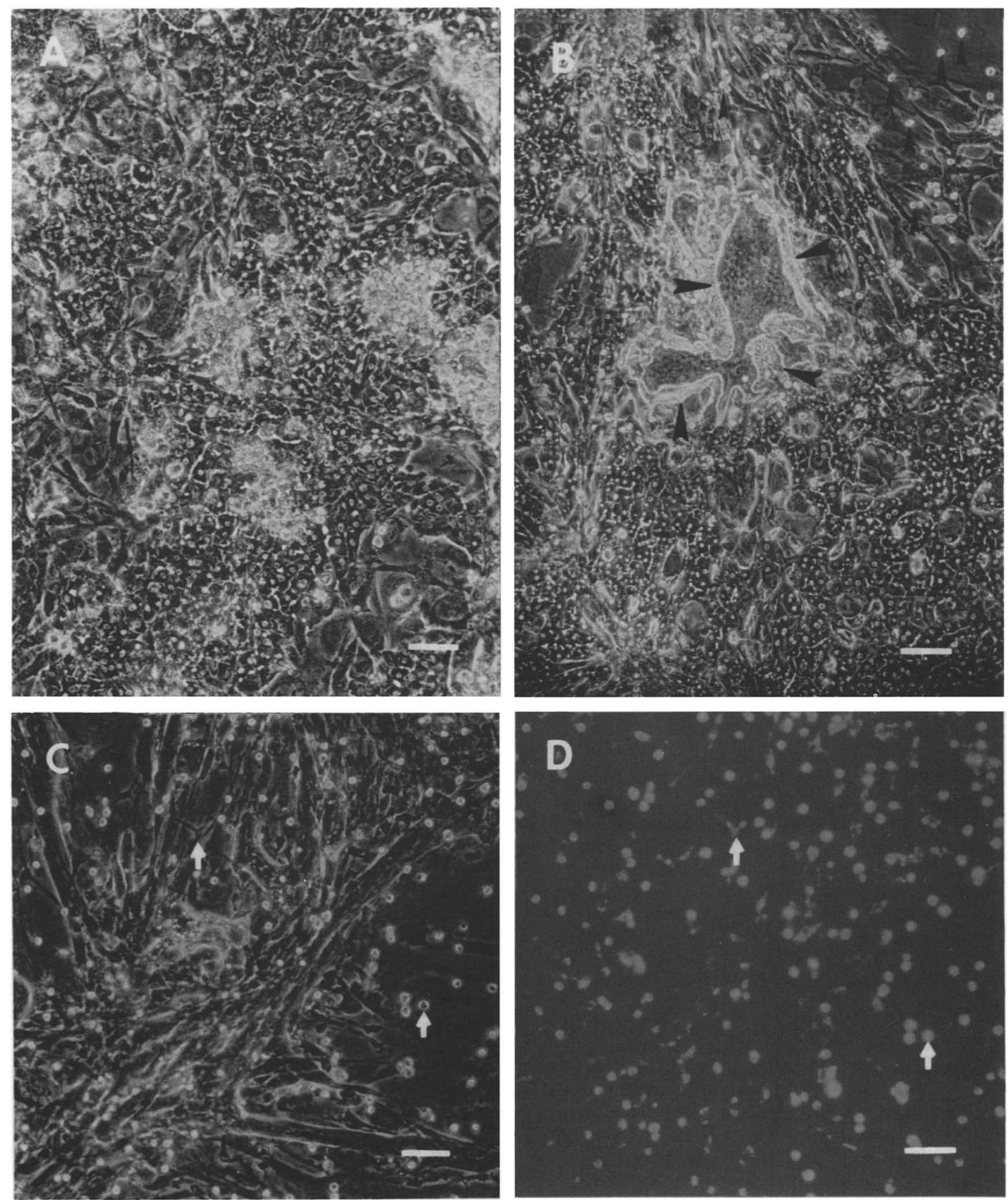

FIG. 1. Phase-contrast microscopy of primary and secondary cultures of adult pig hepatocytes on STO feeder cells. A, Attachment of primary hepatocyte/BDE monolayer at $3 \mathrm{~d}$ postplating. Bar $=90 \mu \mathrm{m} . B$, Primary hepatocyte/BDE monolayer at 3 wk postplating; note colonial outgrowth of bile duct epithelial cells (large arrowheads) and macrophages (small arrowheads). Hydrocortisone $(3.6 \mu \mathrm{g} / \mathrm{ml}) \mathrm{was}$ added to the medium in an attempt to suppress the macrophage outgrowth. Bar $=90 \mu \mathrm{m}$. $C$, Primary hepatocyte/BDE monolayer degenerating under macrophage overgrowth; note numerous macrophages, round or flat morphology (arrows), and the loss of healthy hepatocyte morphology. Bar $=44 \mu \mathrm{m}$. D, Same field as in $C$, but stained with DiI-Ac-LDL to fluorescently mark the macrophages (red fluorescence). Bar $=47 \mu \mathrm{m}$. 

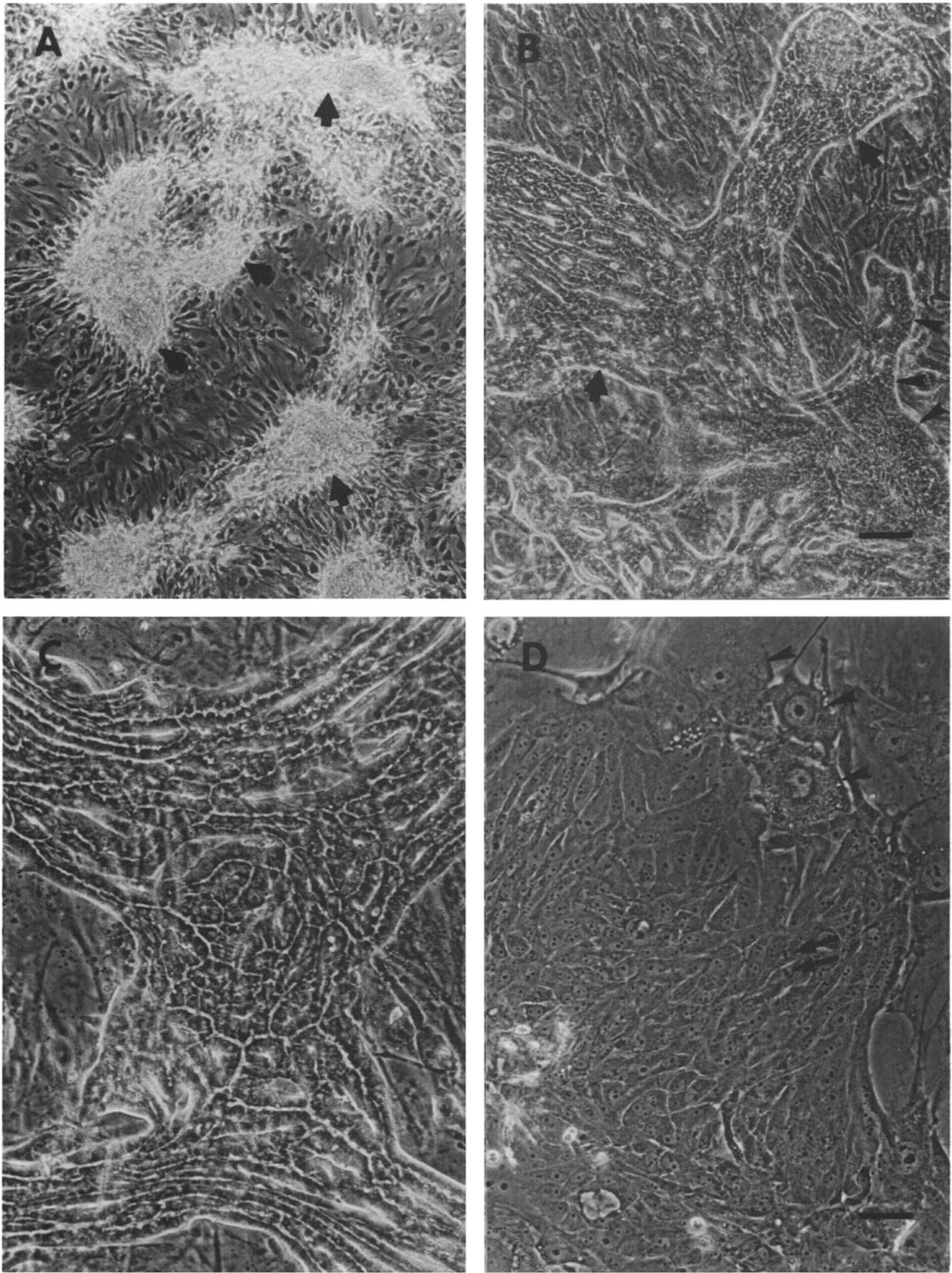

FIG. 2. Phase-contrast microscopy of secondary cultures of adult pig BDE cells derived from freeze-thaw purification protocol at Passage 1. A, Low power photomicrograph of $1 \mathrm{wk}$ postpassage outgrowth; note piles of proliferating BDE cells (arrows). B, Low power photomicrograph of BDE outgrowth at 2-3 wk postpassage; note fully differentiated ductal monolayers (arrows) and the adjacent undifferentiated portion (arrowheads). For $A$ and $B, B a r=98 \mu \mathrm{m}$. C. High power photomicrograph of fully differentiated BDE cells forming multicellular ductal structures at 2-3 wk postpassage; note compact columnar BDE cell morphology. $D$, High power photomicrograph of undifferentiated BDE cell monolayer passaged one time off of STO feeder cells (1:2 split ratio); note some STO feeder cells that survived and reattached after passage (arrowheads) and metaphase plates of two dividing BDE cells (arrows). For $C$ and $D, B a r=50 \mu \mathrm{m}$. 

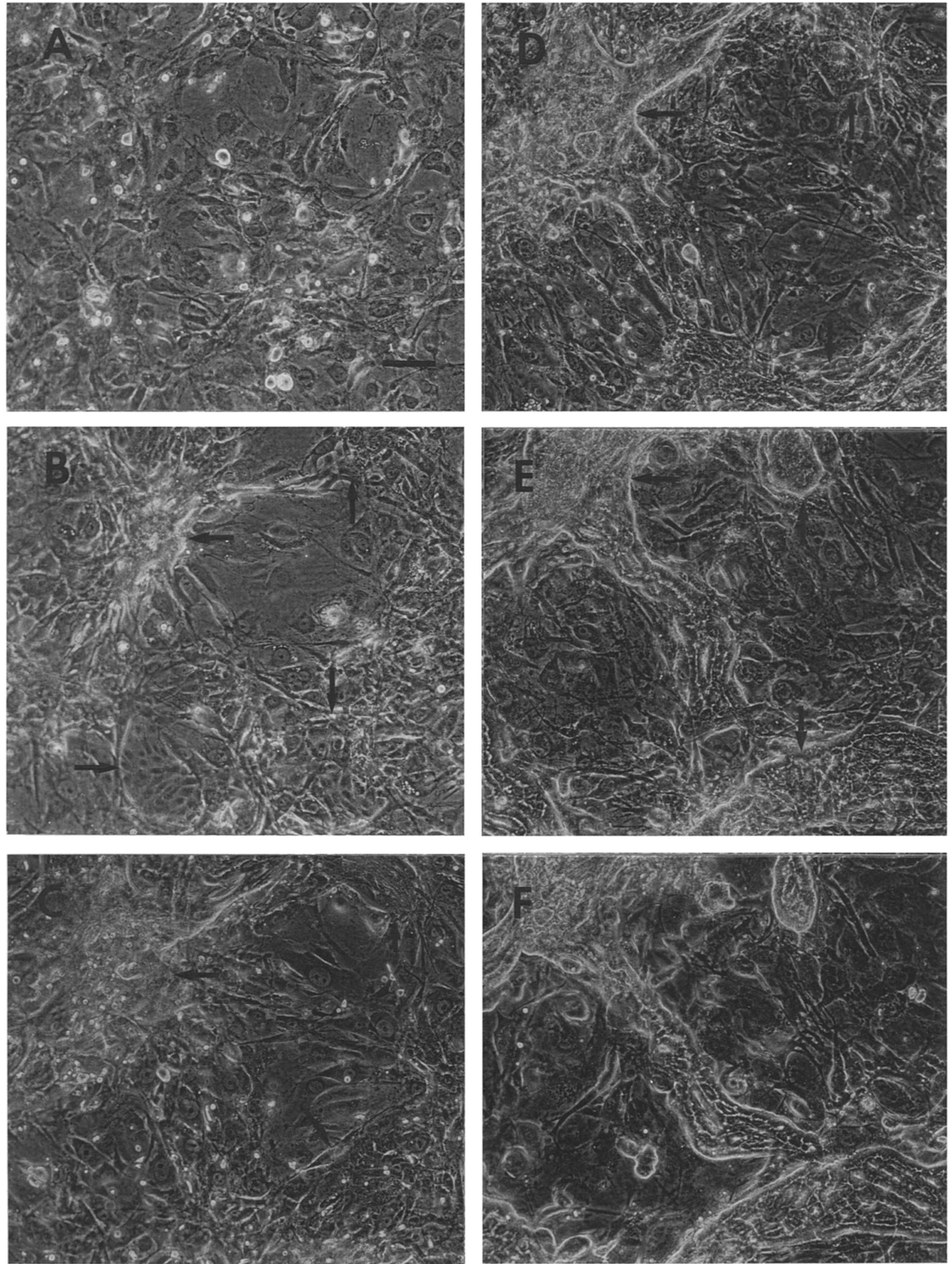

FIG. 3. Phase-contrast microscopy of the same area of a BDE cell culture (Passage 1) over a $21 / 2$-wk period. A, BDE culture 24 h after passage by trypsin-EDTA treatment; note that the individual BDE cells were not easily discernible against the STO feeder cell monolayer. $B$, BDE cell growth at $72 \mathrm{~h}$ postpassage indicated by arrows. $C$, BDE cell growth at $7 \mathrm{~d}$ postpassage indicated by arrows. $D$, BDE cell growth at $9 \mathrm{~d}$ postpassage indicated by arrows; note the movement of individual groups of BDE cells in relation to STO feeder cells. $E$, BDE cell growth at $15 \mathrm{~d}$ postpassage indicated by arrows; note the BDE cells have begun to polarize and form ductal structures. $F, \mathrm{BDE}$ cell growth and differentiation at $19 \mathrm{~d}$ postpassage; note differentiated ductal structures. $\mathrm{Bar}=100 \mu \mathrm{m}$. 


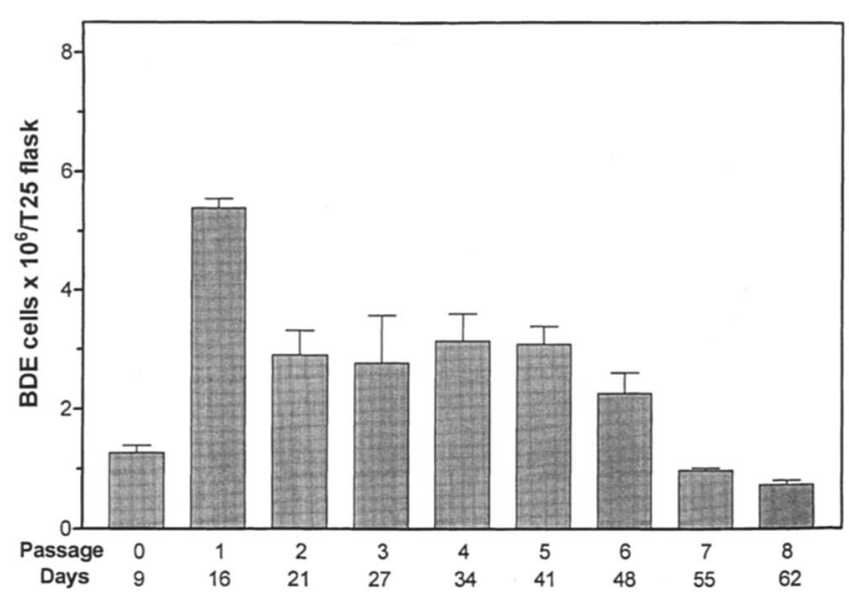

FIG. 4. Cell count growth assay of BDE cells. BDE cultures were initiated from frozen/thawed adult pig liver cell preparations. Endothelium-like cells were physically removed at primary culture (see "Results"). Surviving hepatocytes and macrophage in the primary culture were estimated to represent less than $1 \%$ of the cells in the primary culture, and these cells were lost over passage (1:2 split ratio) by lysis or senescence, respectively. Each data point represents the mean of eight hemocytometer square $\left(1 \mathrm{~mm}^{2}\right)$ cell counts. Total number of BDE cells was obtained by subtracting the number of STO feeder cells counted in control flasks without BDE cells from the total of cells in BDE flasks.

be selectively propagated on STO feeder cells, and that they spontaneously mature to a polarized state with ultrastructural/enzymatic features typical of in vivo liver BDE. A simple isolation and culture method for pig BDE is also described.

\section{Materials and Methods}

Cell culture. All cells were grown on tissue culture plasticware (Nunc, Roskilde, Denmark; and Falcon, Becton/Dickinson, Lincoln Park, NJ). Cryovials $(2 \mathrm{ml})$ were purchased from Nunc. Fetal bovine serum (FBS) was obtained from GIBCO, Gaithersburg, MD or from HyClone Laboratories, Logan, UT. Cell culture reagents including Dulbecco's phosphate-buffered salinel(PBS) without $\mathrm{Ca}^{++}$and $\mathrm{Mg}^{++}$, media, trypsin-EDTA (0.025\% trypsin, $0.43 \mathrm{~m} M$ EDTA), antibiotics, nonessential amino acids, and L-glutamine were from GIBCO. STO feeder cells (CRL 1503, American Type Culture Collection, Rockville, MD) were prepared as described by Robertson (1987).

Adult pig hepatocyte preparations were obtained by collagenase perfusion and differential centrifugation essentially as previously described (Caperna et al., 1985) except only 80-100 g of the left lateral lobe was used. Mixed primary cultures of pig hepatocytes and bile duct epithelium were initiated by plating $1 \times 10^{6}$ cells from freshly prepared adult pig hepatocyte preparations or $2 \times 10^{6}$ cells from frozen/thawed adult pig hepatocyte preparations into T25 tissue culture flasks containing feeder layers of STO mouse fibroblast cells. Cells were plated in $6 \mathrm{ml}$ of 10\% DMEM-199 medium [1:1 mixture of Dulbecco's modified Eagle's medium (DMEM) supplemented with 10\% FBS, 2-mercaptoethanol (2-ME) $(0.1 \mathrm{~m} M)$ from Sigma Chemical Co. (St. Louis, MO), nucleosides $(0.03 \mathrm{~m} M$ guanosine, $0.03 \mathrm{~m} M$ adenosine, $0.03 \mathrm{~m} M$ cytidine, $0.03 \mathrm{~m} M$ uridine, and $0.01 \mathrm{~m} M$ thymidine) from Sigma, nonessential amino acids $(1 \times)$ and glutamine $(2 \mathrm{mM})$, antibiotics (Robertson, 1987), and Medium 199 supplemented with 10\% FBS, 2-ME, and antibiotics]. Cell cultures were routinely passaged at a 1:2 split ratio after treatment with trypsinEDTA.

Dil-acetylated low-density lipoprotein uptake by macrophages. Macrophages were shown to take up acetylated LDL by specific receptor-mediated processes (Goldstein et al., 1979). BDE cultures were exposed to $1,1^{\prime}$-dioctadecyl-3,3,3',3'-tetramethylindo-carbocyanine perchlorate-acetylated lowdensity lipoprotein (DiI-Ac-LDL) at $10 \mu \mathrm{g}$ per ml of $10 \%$ DMEM for $4 \mathrm{~h}$ at $37^{\circ} \mathrm{C}$ according to the manufacturer's instructions (Biomedical Technologies
Inc., Stoughton, MA). Uptake of the DiI-Ac-LDL was visualized with a standard rhodamine excitation/emission filter set on an Olympus IMT-2 inverted microscope fitted with an Olympus IMT-2 reflected light fluorescence attachment (Opelco, Washington, DC).

$P-450$ enzyme content assay. Two-to-four-wk-old adult pig BDE cultures, or STO feeder cells alone were exposed to metyrapone (Sigma) at $0.5 \mathrm{~m} M$ in complete medium for $48 \mathrm{~h}$. T25 flasks of cells were scraped and microsomal fractions were prepared as previously described (Talbot et al., 1996). The concentration of cytochrome P-450 was determined spectrophotometrically on fresh microsome fractions as described by Omura and Sato (1964). A difference spectrum between 400 and $500 \mathrm{~nm}$ was obtained (Lambda 3B, Perkin-Elmer Corp., Norwalk, CT) for samples which were reduced with solid sodium hydrosulfite (S-2156, Sigma) in the presence or absence of carbon monoxide. Protein content of microsome and homogenate fractions was determined by the method of Nerurkar et al. (1981) with bovine albumin as standard.

$\gamma$-glutamyl transpeptidase assay. Total cellular activity of $\gamma$-glutamyl transpeptidase (GGT) was determined on freshly prepared homogenate material essentially by the method of Jacobs (1971) with the following modifications. The complete reaction mix containing L- $\gamma$-glutamyl-p-nitroanilide and glycylglycine (Sigma) as substrates was incubated with samples for 10 and 40 min at $37^{\circ} \mathrm{C}$, and the $\mathrm{NaOH}$ stopping-solution contained Triton $\mathrm{X}-100$ $(0.2 \%)$. The concentration of $p$-nitroaniline was determined spectrophotometrically at $405 \mathrm{~nm}$, and enzyme activity was determined over the 30-min time interval.

$\gamma$-glutamyl transpeptidase histochemistry. Histochemical localization of GGT was determined by the method of Rutenberg et al. (1969) on BDE cultures that were fixed for $2 \mathrm{~min}$ with ice-cold methanol just before the addition of substrate solution.

Ricin A ablation of liver-derived macrophages. Pig liver macrophage outgrowths were removed by treatment of primary hepatocyte/BDE monolayers with ricin A (Sigma, L 9514) at $10 \mathrm{ng} / \mathrm{ml}$ in serum-free DMEM-199 for $1 \mathrm{~h}$ at $37^{\circ} \mathrm{C}$ at approximately $5 \mathrm{~d}$ postplating according to the method of Johnston et al. (1996).

Transmission electron microscopy (TEM). Transmission electron microscopy sample preparation and photomicroscopy was done with the assistance of JFE Enterprises, Brookeville, MD. A 3- to 4-wk-old culture of pig BDE cells at Passage 4 was fixed in situ with $2.5 \%$ glutaraldehyde for $2 \mathrm{~h}$ followed by Millonig's phosphate buffer washes (Dawes, 1971). The culture was postfixed in $1 \%$ osmium tetroxide for $1 \mathrm{~h}$. Following dehydration in an ethyl alcohol series $(70 \%$ to $100 \%$, and propylene oxide transitional fluid), the cultures were infiltrated with plastic resin (Spurr's) and polymerized in a $70^{\circ} \mathrm{C}$ oven. Ultrathin sections ( 60 to $80 \mathrm{~nm}$ ) were stained with $2 \%$ uranyl acetate for $1 \mathrm{~h}$ before examination with a Ziess EM10 CA transmission electron microscope.

\section{RESUlts}

Selective culture of adult pig intrahepatic bile duct epithelial (BDE) cells. Freshly isolated adult pig hepatocytes were plated onto STO feeder cells at $1 \times 10^{6}$ cells/T25 flask in $6 \mathrm{ml}$ of $10 \%$ DMEM-199. The cultures were fluid-changed with $6 \mathrm{ml}$ of fresh 10\% DMEM-199 the $\mathrm{d}$ after cell attachment. In the first wk, the primary culture appeared to consist mainly of cobblestone-shaped hepatocytes which established a nearly confluent monolayer on top of the STO feeder layer (Fig. $1 A$ ). Biliary canaliculi developed between the hepatocytes after the first few d of culture (Fig. $1 A$ and $B$ ). Areas of bile duct epithelium were evident after 1-2 wk of primary culture as multicellular ductal structures composed of pseudocolumnar cells arranged with a conspicuous apical and basolateral orientation (Fig. 1 $B)$. Liver macrophage outgrowths, identified by morphology and DiIAc-LDL staining (Talbot and Paape, 1996) were first observed after about 1 wk of primary culture (Fig. $1 B, C$ and $D$ ).

The outgrowth of the liver macrophages could build up to several million macrophages per T25 flask over 2-3 wk in primary culture. The macrophage proliferation, presumably accompanied by macrophage activation, resulted in a loss of monolayer integrity after a few wk. That is, the STO feeder layer with its attached hepatocyte/BDE 


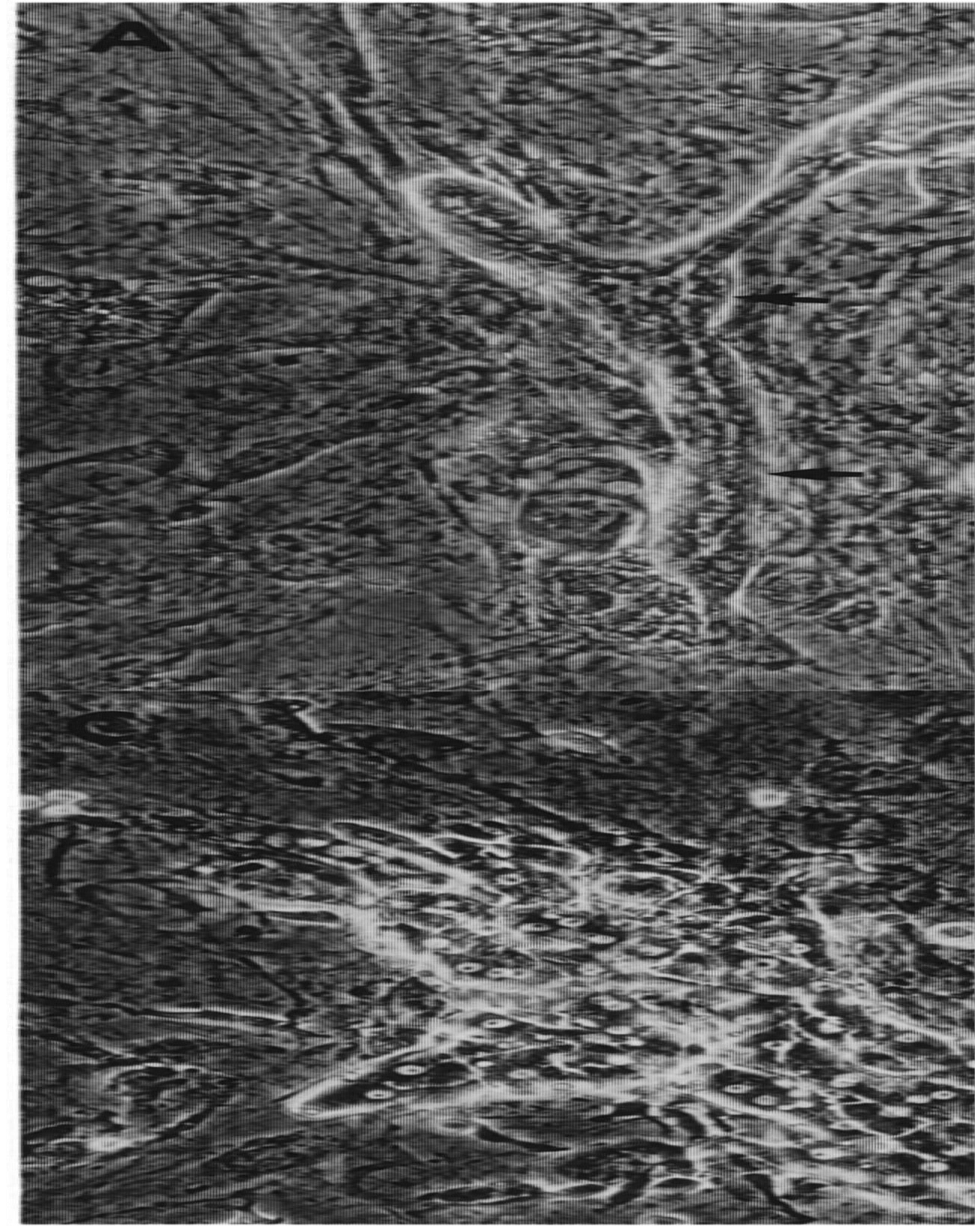

FIG. 5. Phase-contrast microscopy of secondary culture and GGT histochemical staining of adult pig BDE cells. A, Differentiated colonial outgrowth of BDE culture \#2 at Passage 4; polarized multicellular ductal morphology (arrows). B, Histochemical staining of GGT activity of BDE culture \#l at Passage 5; note intense luminal staining at the apical surfaces of the BDE cells. $C$, Largest of three surviving pig hepatocyte patches found in BDE culture \#1 (T25 flask) at Passage 5; note large cobblestone morphology with well-developed biliary canaliculi between most cells. $D$, Histochemical staining of hepatocyte patch shown in $C$; note lack of staining except for a few BDE cells embedded in the patch of hepatocytes. Bar $=50 \mu \mathrm{m}$. 


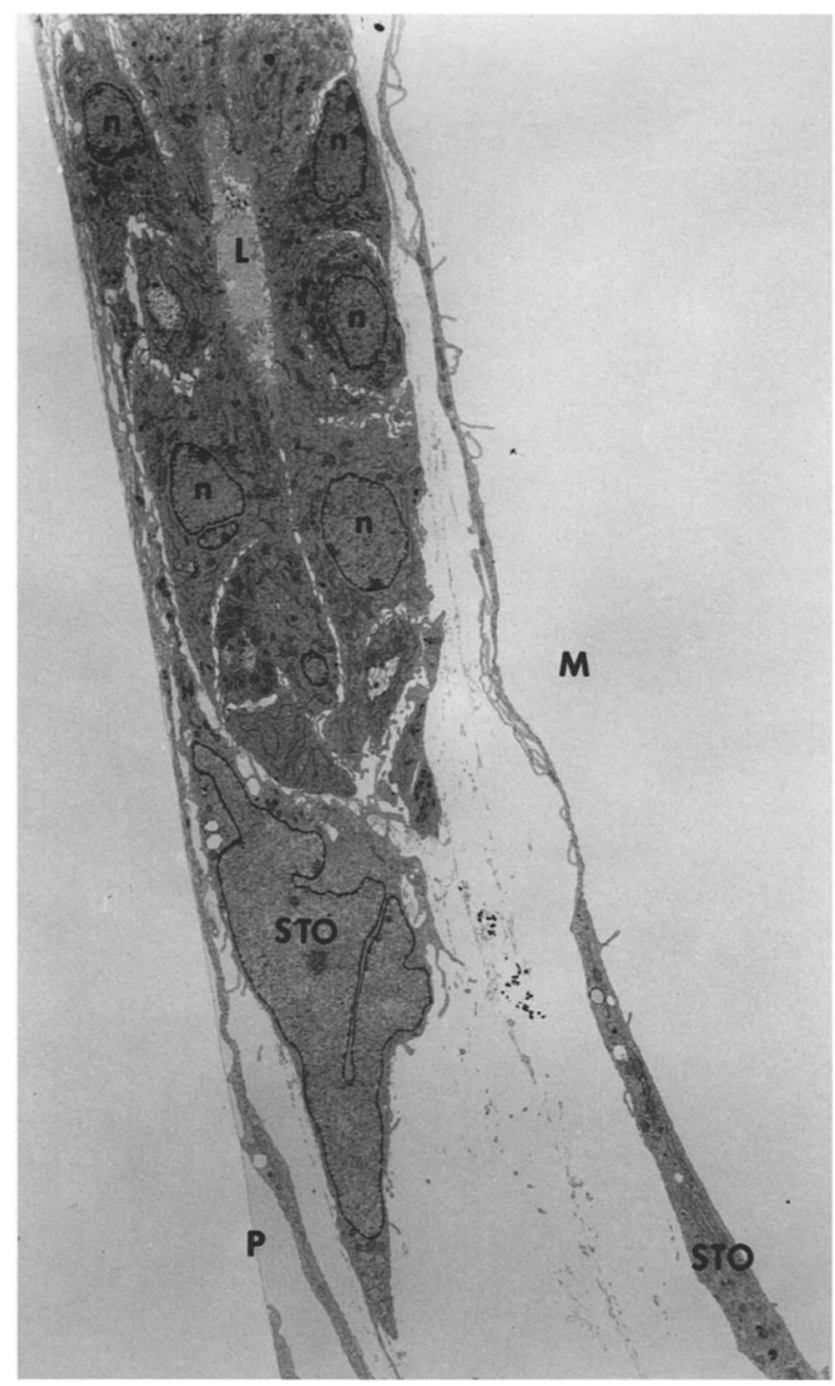

FIG. 6. TEM of a BDE colonial outgrowth at Passage 4. Several BDE cells compose the circumference of the in vivo-like ductal structure. BDE cells have oval, basolaterally located nuclei (n) and microvilli and cilia projecting into the ductal lumen (L). Note the sandwich-like arrangement of the STO feeder cells above and below the BDE multicellular ductal structure. Tissue culture plastic surface $(\mathrm{P})$ is left, and medium surface $(\mathrm{M})$ is right. Magnification, $\times 2150$.

would degrade and eventually detach (Fig. $1 C$ and $D$ ). Addition of hydrocortisone $(3-4 \mu \mathrm{g} / \mathrm{ml})$ to the medium suppressed the macrophage outgrowth and slowed, but did not stop, the eventual loss of the culture (Fig. $1 B$ ). To stop the macrophage overgrowth and loss of the monolayer, 1-wk-old primary cultures were exposed to $10 \mathrm{ng}$ ricin A per $\mathrm{ml}$ in serum-free DMEM-199 for $1 \mathrm{~h}$ according to the method of Johnston et al. (1996). This procedure eliminated most or all of the macrophages but left the STO feeder cells, pig hepatocytes, and pig BDE cells unharmed. Sometimes macrophage outgrowth recurred as a discrete colony after ricin A treatment which presumably arose from a clonal expansion. The proliferative capacity of postricin A macrophages was limited, and the macrophages were diluted out over subsequent passages.

Secondary passage (1:2 split ratio) of the pig hepatocyte/BDE cultures was performed with trypsin-EDTA after $2-3 \mathrm{wk}$ in primary
TABLE 1

LEVELS OF CYTOCHROME P-450 AND ACTIVITY OF $\gamma$-glutamyl transpeptidase (GGT) in bile duct epithelial cells from adult porcine liver cultured on STO-feeder cells

\begin{tabular}{lcccc}
\hline & $\begin{array}{c}\text { P-450 } \\
\text { (pmoles/flask) }\end{array}$ & $\begin{array}{c}\text { P-450 } \\
\text { (pmoles/mg } \\
\text { microsomal } \\
\text { protein) }\end{array}$ & $\begin{array}{c}\text { GGT } \\
\text { (munits/flask) }\end{array}$ & $\begin{array}{c}\text { GGT } \\
\text { (munits/mg } \\
\text { total protein) }\end{array}$ \\
\hline $\begin{array}{c}\text { Bile duct cells } \\
\text { Whole liver }\end{array}$ & $11.7 \pm 7.2$ & $\begin{array}{c}17.8 \pm 9.9 \\
760 \pm 69\end{array}$ & $227 \pm 28$ & $75.2 \pm 7.6$ \\
\hline
\end{tabular}

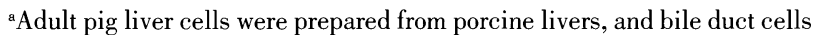
were cultured as described. All cultures were harvested between 10 and 33 days following initiation of culture (passage 2 through 5) and $48 \mathrm{~h}$ after addition of metyrapone $(0.5 \mathrm{~m} M)$. Values for bile duct cells represent means \pm SEM of 6 independent determinations. Two or three flasks of cells were pooled for each determination. Total protein in cocultures was $3.01 \pm 0.19$ mg per flask, whereas protein associated with independent cultures of STO cells grown under similar conditions $(\mathrm{n}=5)$ was $1.20 \pm 0.13 \mathrm{mg}$ per flask. Microsomal protein was 21 and $24 \%$ of the total protein in cocultures and STO cultures, respectively. P-450 was undetectable in STO cells and GGT activity associated with STO cells was below limits of detection.

${ }^{\mathrm{b}} \mathrm{Homogenates}$ and microsomes were prepared from freshly harvested livers of $82-\mathrm{kg}$ pigs $(\mathrm{n}=4)$ and P-450 and GGT were determined as for cell preparations.

culture. At this point, approximately $95 \%$ of the cells appeared to be well-differentiated hepatocytes as estimated from microscopic observation (Fig. $1 A$ and $B$ ). The other $5 \%$ was composed of BDE cells observable as developing multicellular ductal structures (Fig. $1 B$ ). First passage resulted in a dramatic loss of hepatocytes, presumably from cell lysis as cells were separated from one another. The pig BDE cells appeared to tolerate passage much better and represented over $50 \%$ of the surviving cells at Passage 1. By Passage 3-4, few or no hepatocytes could be found in the cultures, whereas the BDE continued to survive and grow from single cells or small clumps of cells. Pig hepatocytes were not observed to proliferate. Three independent pig BDE cell cultures were established from three pigs ranging from 3-5 mo. of age.

Efficient method for the isolation of pig intrahepatic bile duct epithelium (BDE). A simple method for the isolation of BDE cells was discovered. Freshly prepared adult pig hepatocytes at $2 \times 10^{7}$ cells/ cryovial were frozen in FBS with $10 \%$ dimethylsulfoxide as cryopreservative by quick-freezing the cyrovials in liquid nitrogen. After several mo., the hepatocyte preparation was thawed in a $37^{\circ} \mathrm{C}$ water bath, washed one time by centrifugation, resuspended in $10 \%$ DMEM-199, and immediately plated at $2 \times 10^{6}$ cells/T25 flask containing a confluent layer of STO feeder cells. The medium was replaced with fresh 10\% DMEM-199 after 24 h. This freezing and thawing of the hepatocyte preparation destroyed all of the hepatocytes and all or most macrophages, leaving only BDE and endothelial-like cells viable.

After 1 wk of culture, 50-100 primary colonies of BDE were observed growing on top of the STO feeder cells as compact mounds consisting of several hundred cells. Five to 10 colonies of liver endothelial-like cells were also observed growing on the plastic as closely knit, flattened cells which displaced the STO feeder cells as they expanded outward (not shown). The endothelial-like cell colonies were removed by mouth-controlled aspiration with a drawn-out Pasteur pipette before secondary passage to create essentially pure 


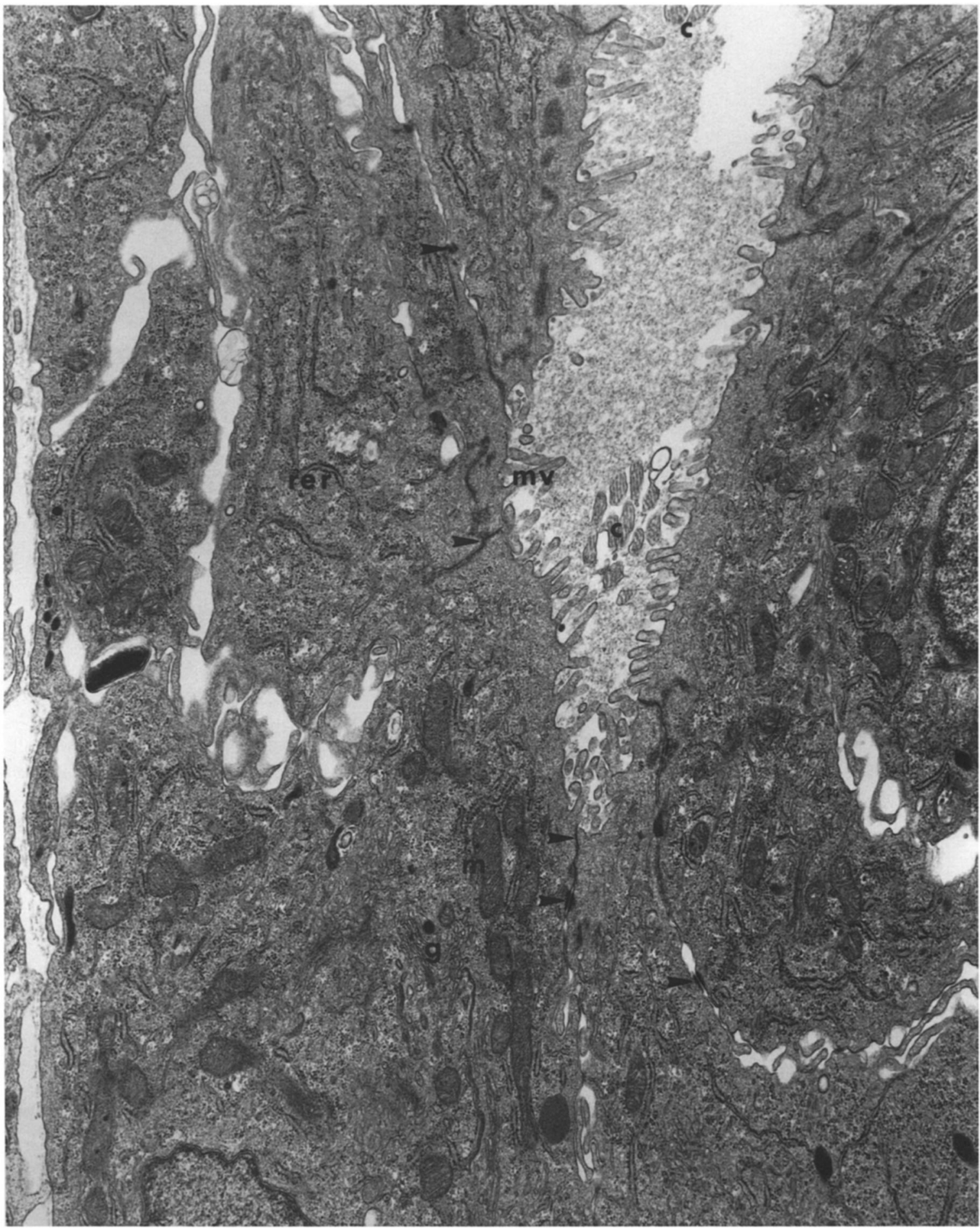

FIG. 7. TEM of BDE multicellular ductal structure lumen. Numerous microvilli (mv) and cilia (c) protrude into the lumen at the apical surfaces of the BDE cells. Microvilli also form interdigitations along the lateral surfaces of adjacent cells. Desmosomes are evident at the lateral surfaces of the cells in addition to tight junctional complexes which appear adjacent to the lumen between the cells (arrowheads). Note mitochondria $(\mathrm{m})$ with flat cristae and dense matrix, Golgi apparatus $(\mathrm{g})$, and rough endoplasmic reticulum (rer). Magnification, $\times 15200$. 


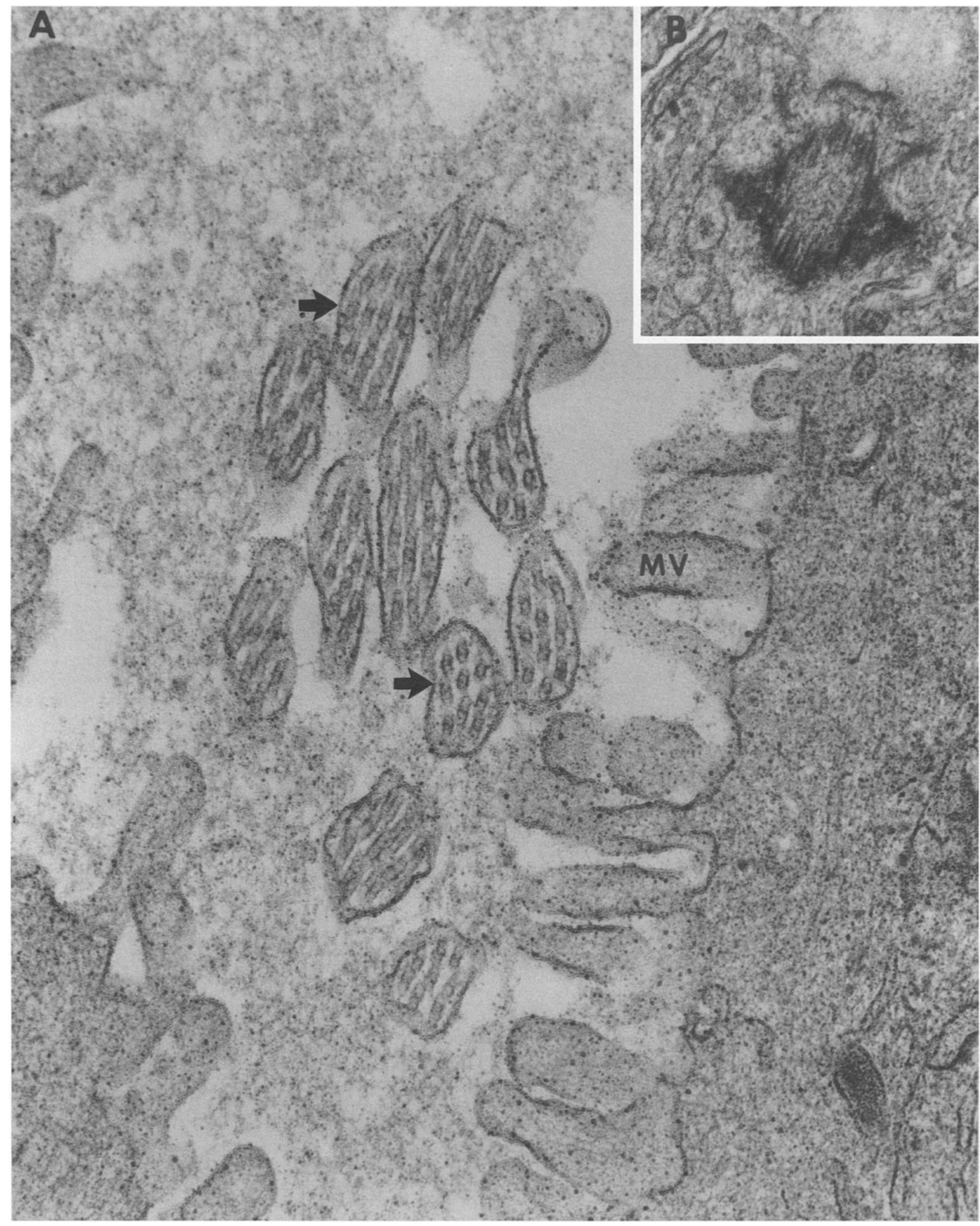

FIG. 8. A, TEM of BDE luminal cilia (arrows; tangential section) and microvilli (mv). $B$, Insert showing cilium basal body (tangential section) found in the apical membrane of a BDE cell pictured in Figs. 4 and 5. Magnification, $\times 160000$. 


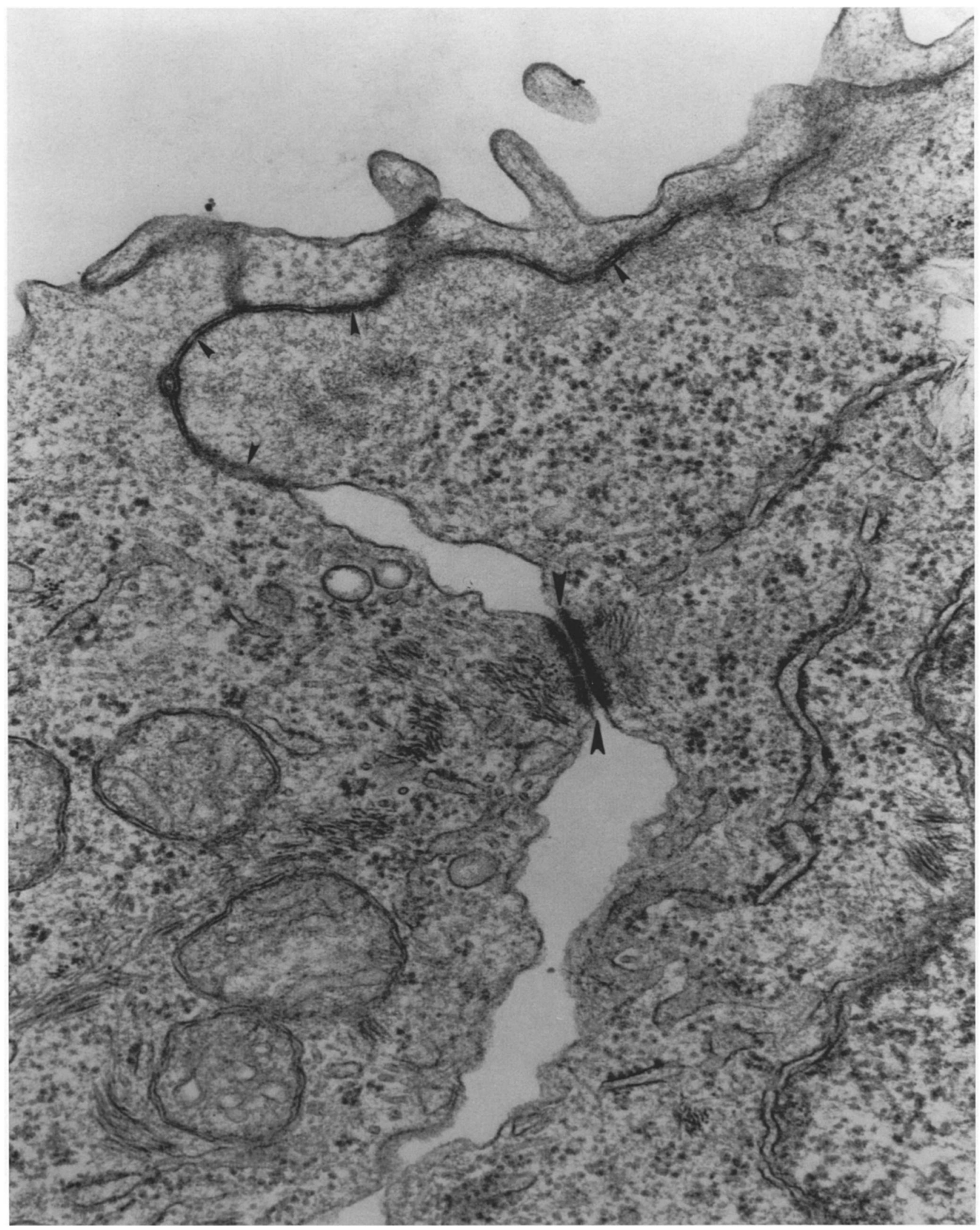

FIG. 9. TEM of BDE desmosome (large arrowheads) and associated tight junctional area (small arrowheads) at the luminal apical surface. Magnification, $\times 67000$. 


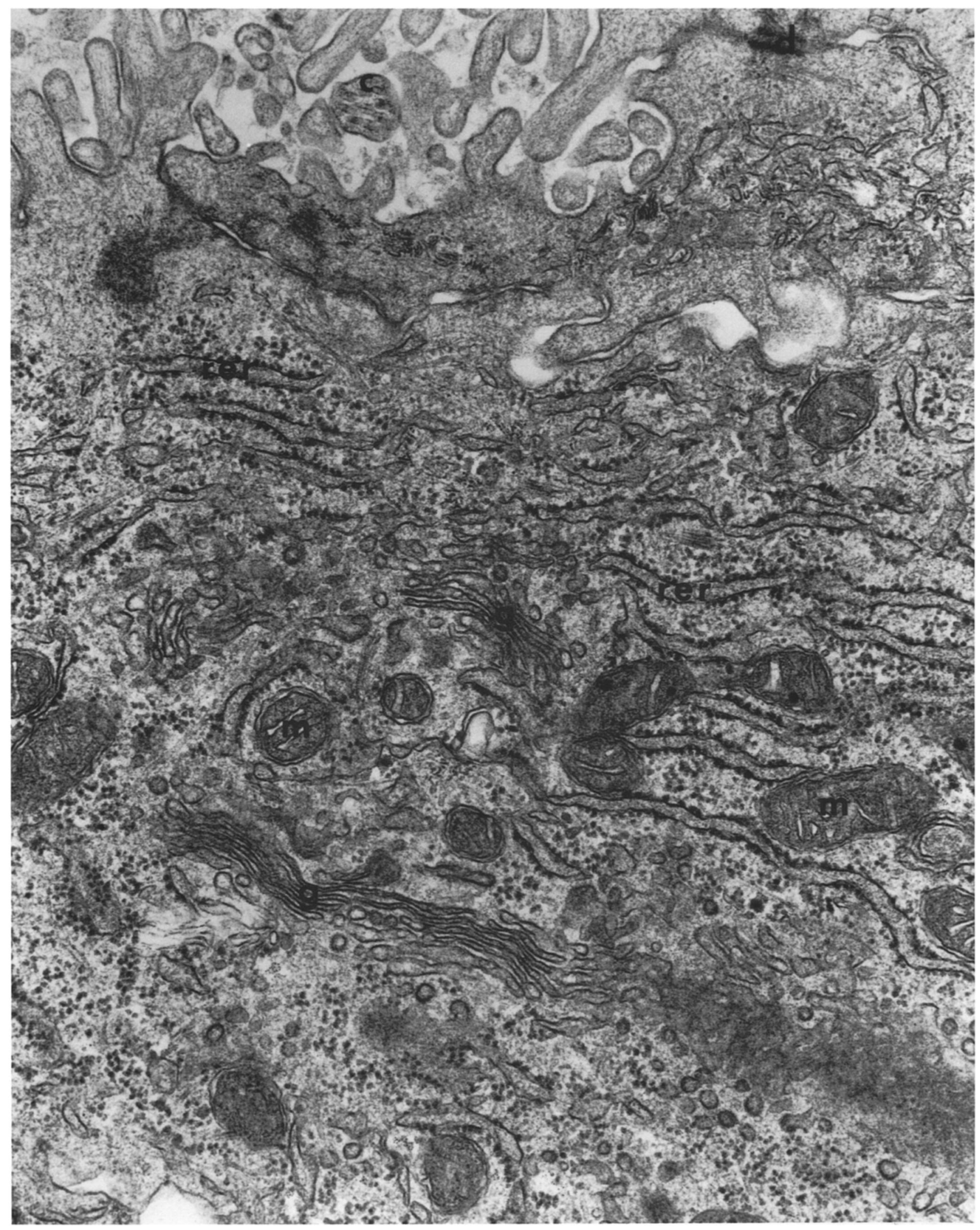

FIG. 10. TEM of BDE Golgi apparatus (g), mitochondria (m), rough endoplasmic reticulum (rer), cross-section of cilia (c) and desmosome (d). Magnification, $\times 54000$. 
cultures of BDE. The secondary BDE cultures grew robustly as mounds of cells or as monolayers extending out from the mounds (Fig. 2 A). After 2-3 wk in static culture, the BDE cells spontaneously differentiated into polarized duct-like structures as previously noted from BDE cells derived from the hepatocyte cocultures described above (Fig. $2 B$ and $C$ ). The pig BDE cells grew slowly from single cells or clumps of $2-4$ cells at each passage (1:2 split ratio) with estimated doubling times of 1-2 d (Figs. 3 and 4). One to $2 \mathrm{~d}$ after each passage, BDE cells could not be easily discerned on the STO feeder layer (Fig. $3 A$ ). After 3-4 d, however, individual colonial outgrowths composed of 5-10 cells appeared at random across the feeder layer (Fig. $3 \mathrm{~B}$ ). The BDE grew as closely connected and compact cell colonies (Figs. 2 and 3). The number of cells in each colony increased over 1-2 wk of culture, although the final size of individual colonies varied (Figs. 2 and 3). Some colonies were composed of hundreds of cells while others were made up of only 5-10 cells (Figs. 2 and 3). The BDE cultures could be passaged (1:2 split ratio) about 4-6 times on to fresh STO feeder layers before losing replicative capacity (Fig. 4). BDE cells passaged off STO feeder layers one time spread out and replicated on the bare plastic to fill in the available space between surviving STO cells that reattached after passage (Fig. $2 \mathrm{D}$ ). BDE cells that were subcultured off of STO cells for more than one passage reattached, but instead of replicating, the BDE cells became flattened, spread out, and appeared to senesce over a period of 1-2 wk. Also, BDE cultures with little or no STO support could be taken over by fibroblast outgrowths, particularly at early passage levels. If the BDE cells were passaged on and off STO feeder cells at alternate passages, their longevity in culture did not appear to be increased.

Characterization of pig bile duct epithelium (BDE). The BDE colonial outgrowths differentiated, i.e., stopped dividing, and adopted a polarized nature with fluid transport at $2-3 \mathrm{wk}$ postpassage. Many of the colonies developed domes as they actively transported fluid into their ductal lumens (Fig. $5 \mathrm{~A}$ ). In situ assay showed these mature, colonial, multicellular structures to be rich in GGT activity (Fig. 5 B), an enzymatic marker of BDE (Tanaka, 1974; Ishii et al., 1989). GGT staining was most intense on the luminal or apical surface of the BDE cells and least intense at the basolateral surface. A surviving patch of hepatocytes showed little or no GGT staining (Fig. $5 C$ and $D$ ). Biochemical analysis also demonstrated BDE cell culture lysates to be high in GGT activity relative to whole pig liver tissue (Table 1). GGT activity was not detected in STO feeder cells alone. $\mathrm{P}-450$ levels were very low or absent in metyrapone-induced cultures of the BDE cells (Table 1). The BDE cultures derived from the freeze/ thaw method had similarly high GGT activity and had little or no inducible P-450 (Table 1).

Transmission electron microscopic (TEM) examination showed the mature pig BDE colonial outgrowths were well-organized multicellular structures with striking resemblance to in vivo pig intrahepatic bile ducts (Singh and Shahidi, 1987). The BDE cells were organized as tubular structures with several cells composing the overall circumference (Fig. 6). Some of the STO feeder cells, all initially underneath the BDE, migrated above the multicellular BDE structure to produce a sandwich-like arrangement (Fig. 6). No basement membrane was obvious between the STO cells and the BDE cells. The BDE cells had a polarized morphology whereby the cytoplasmic surface facing the lumen was specialized with numerous microvilli and cilia (Fig. 7). The presence of cilia protruding into the ductal lumen was particularly characteristic of in vivo intrahepatic BDE (Fig. 8).
Nuclei were generally oval and basolaterally located (Fig. 6), and tight junctions with associated desmosomes were prominent near the apical unions of the cells (Figs. 7 and 9). Other prominent intracellular features were the extensive rough endoplasmic reticulum and numerous free polyribosomes, and the extensive Golgi apparatus, indicative of cells with high protein production and secretory activity. Numerous oblong mitochondria with flat cristae extending into a relatively dense mitochondrial matrix were found in the BDE cells (Figs. 7 and 10). Glycogen rosettes, typical of hepatocytes, were not observed in the BDE cytoplasm.

\section{DISCUSSION}

The culture of relatively crude preparations of adult pig liver cells on STO feeder cells in serum-containing medium supports the growth and selective isolation of pig bile duct cells that spontaneously polarize to form duct-like structures. Adult pig hepatocytes were not observed to replicate on the STO feeder cells, and their numbers in the cultures approached zero over the first few secondary passages. In contrast, the BDE cells did replicate, albeit to a limited extent.

The differentiation of the pig BDE cells was dramatic in the STO coculture, and it was very similar to the multicellular ductal formation previously observed in the pig epiblast-derived PICM-19 liver stem cell line (Talbot et al., 1994a; 1996). The pig BDE ductal structures were similar to normal liver in that they possessed cilia, a feature typical of pig intrahepatic bile ductules (Singh and Shahidi, 1987). In contrast, the ductal structures formed by PICM-19 cells apparently lacked cilia, perhaps reflecting incomplete differentiation and organotypic structure (Talbot et al., 1996). Other ultrastructural features and the expression of GGT by the BDE cells were similar to in vivo liver ductules, and to in vitro multicellular ductal structures formed by PICM-19 cells (Tanaka, 1974; Meister et al., 1976; Talbot et al., 1996). GGT is highly expressed in bile duct epithelium and thought to be a good marker for this cell type (Tanaka, 1974; Ishii et al., 1989). GGT activity was expressed at or near the apical portion of the BDE cell membrane directly adjacent to the lumen of the ductal structures. No staining was observed on the outer aspect of the ductal structures, indicating a well-polarized condition within the BDE cells (Fig. 1). A similar polarized and apical distribution of GGT was demonstrated in acinar cells of the pancreas (Rutenberg et al., 1969), in the canalicular regions of hepatocytes, and in bile duct epithelium (Meister et al., 1976). This polar distribution of GGT was indicative of the transport function of the enzyme in the specialized apical areas of these cells (Meister et al., 1976).

The limited serial propagation of the BDE cells (4-8 passages) may represent the "normal" population doubling capacity of adult pig BDE or the effect of ongoing terminal differentiation in the cultures. The results of Joplin et al. (1992) with the HGF-dependent culture of human bile duct cells appeared to be similar to our results with pig BDE in that the human bile duct cultures were passaged about five times over a 3-mo. period. Similar results were obtained with rat bile duct cells cultured by Mathis et al. (1988). However, the rat bile duct cultures of Vroman and LaRusso (1996) were relatively long-lived, being passaged 70 times over a 22 -mo. period. The authors did not indicate noting a senescent crisis and transformation event which might explain the longevity of their cultures, given that rat cells could be expected to have a shorter life span in culture than human and pig cells (Rohme, 1981). However, the actual growth response of cells, and liver cells specifically, has been shown to be 
highly dependent on the surrounding environment (Joplin et al., 1992; Rhim et al., 1994). The lack of culture longevity exhibited by the BDE may have also resulted from the terminal differentiation of significant portions of the cell population at each passage. Terminal differentiation with the loss of growth response in cells forming multicellular ductal structures was previously noted in differentiated pig epiblast-derived bipotent liver stem cell-like cells (Talbot et al., 1994a). However, pig BDE cells alternatively passaged on and off STO feeder cells (Fig. $3 \mathrm{D}$ ), which were therefore largely prevented from forming multicellular ductal structures, could not be serially passaged any longer than those propagated on STO feeder monolayers at each passage.

The growth and differentiation of the pig BDE cells was dependent on STO feeder cells. If the BDE were passaged without the STO cells, they quickly enlarged, lost differentiated form and function, and senesced (not shown). Other culture systems have indicated that a substratum of collagen was required or beneficial to the maintenance and growth of BDE (Vroman and LaRusso, 1996), or the differentiation of the cells into duct-like structures (Paradis and Sharp, 1989; Sirica and Gainey, 1997). Similar observations were made in primary cultures of hepatocytes in that collagen, and, particularly a collagen "sandwich," were effective in maintaining in vivo-like hepatocyte form and function (Dunn et al., 1989; Bader et al., 1992). The STO feeder cells, being mouse fibroblasts, would be expected to produce an extracellular matrix rich in collagen as well as other constituents important in morphogenesis and differentiation of epithelium such as proteoglycans (Linsenmayer, 1991; Toole, 1991). As noted in Fig. 3 , the STO cells also adopt a "sandwich" configuration by arranging themselves above and below the BDE cells. This STO cell migration to a position above the BDE probably takes several $\mathrm{d}$, and the polarization and ductal formation of the BDE takes at least several d. STO "sandwiching" of the BDE may be important to the development of a mature or fully differentiated bile ductule morphology and function.

Feeder cells elaborate specific cytokines, either soluble or membrane bound, that could be potent effectors of pig BDE growth and differentiation. For example, STO cells and other fibroblasts were shown to produce hepatocyte growth factor (HGF) and stimulated ductal formation by kidney epithelial cells in a collagen culture (Montesano et al., 1991a, 1991b). Joplin et al. (1992) demonstrated that HGF induced proliferation of human BDE cells and promoted the maintenance of specific cell functions. Other cytokines that modulate liver function were shown to be produced by STO cells (Rathjen et al., 1990; Schmitt et al., 1991). These included leukemia inhibitory factor (LIF), a liver acute phase-response inducer (Baumann and Wong, 1989) that, along with HGF and granulocyte-macrophage colony-stimulating factor (GM-CSF), stimulated replication of PICM-19 pig liver stem cells (unpublished observations). Thus, the STO feeder cells may represent an in vitro equivalent to the stromal or mesenchymal-derived compartment found in the liver, and the coculture may be mimicking the mesenchymal cell interactions which normally occur in vivo.

It is unclear why pig BDE is responsive to the STO feeder cell environment. Other feeder cell cultures have apparently not produced the same results presented here. For example, the use of Swiss 3T3 fibroblasts as feeder cells facilitated the primary culture of human BDE but did not produce serially passaged cultures or liverlike differentiation (Joplin et al., 1989). NIH/3T3 coculture of SV40 large $\mathrm{T}$ antigen-transformed human BDE showed good replicative capacity (25 passages), but no in vitro ductal formation (Perrone et al., 1995). In the latter case, the lack of in vitro ductular differentiation may have resulted from inappropriate cell cycle stimulation by SV40 large T antigen transformation. However, the nature of the STO fibroblast cell line may be different from Swiss 3T3 and NIH/ 3T3 cells. For example, some lines of Swiss 3T3 and NIH/3T3 were reported to produce negligible amounts of HGF, a key mitogenic cytokine for BDE cells and hepatocytes (Stoker et al., 1987; Montesano et al., 1991b; Joplin et al., 1992). Also, species differences, human vs. pig, may be important. We have previously noted large species differences, i.e., sheep and cow vs. pig, in the mitogenic response of particular cell types, e.g., macrophages, T-lymphocytes and hepatocytes, to coculture on STO feeder cells (unpublished observations).

In summary, our results demonstrated a simple and efficient means for the isolation and secondary culture of adult pig BDE cells. The STO coculture of the pig BDE produced multicellular ductal structures with high apical surface GGT activity similar to that of the BDE found in the intact pig liver. Similar in vitro multicellular ductal formation was previously reported in the pig epiblast-derived PICM19 liver cell line (Talbot et al., 1994a; Talbot et al., 1996). The present results, therefore, support our earlier assertion that PICM19 cells have the characteristics of a bipotential liver progenitor cell. The STO-coculture pig BDE system may be useful in studies of bile duct differentiation and function.

\section{ACKNOWLEDGMENTS}

We thank Ms. Debbie Gavelek for technical assistance with hepatocyte preparations. We also thank Drs. Caird E. Rexroad, Mulumbet Worku, Kimberly Brown, and John M. Talbot for their helpful editorial and scientific comments on the manuscript, and Ms. Shirley Weese for putting the manuscript in final form.

\section{REFERENCES}

Alpini, G.; Phillips, J. O.; LaRusso, N. F. The biology of biliary epithelia. In: Arias, I. M.; Boyer, J. L.; Fasto, N., et al., ed. The liver: biology, and pathobiology. 3rd edition. New York: Raven Press; 1994:623-653.

Bader, A; Christains, U.; Boker, K., et al. In vitro imitation of the in vivo three dimensional microenvironment enables primary hepatocytes to maintain stable metabolic functions. Cell Transplant. 1:162; 1992.

Baumann, H.; Wong, C. G. Hepatocyte-stimulating factor III shares structural and functional identity with leukemia-inhibitory factor. J. Immunol. 143:1163-1167; 1989.

Caperna, T. J.; Failla, M. L.; Kornegay, E. T., et al. Isolation and culture of parenchymal and nonparenchymal cells from neonatal swine liver. J. Anim. Sci. 61:1576-1586; 1985.

Daoust, R.; Cantero, A. The numerical proportions of cell types in rat liver during carcinogenesis by 4-dimethylaminoazobenzene (DAB). Cancer Res. 19:757-762; 1959

Dawes, C. J. Biological techniques in electron microscopy. Burlington, Ladd Research Industries, Inc.; 1971:39.

Demetris, A. J.; Markus, B. H.; Saidman, S., et al. Isolation and primary cultures of human intrahepatic bile ductular epithelium. In Vitro Cell. Dev. Biol. 24:464-470; 1988.

Dunn, J. C. Y.; Yarmush, M. L.; Koebe, H. G., et al. Hepatocyte function and extracellular matrix geometry: long-term culture in a sandwich configuration. FASEB J. 3:174-177; 1989.

Goldstein, J. L.; Ho, Y. K.; Basu, S. K., et al. Binding site on macrophages that mediates uptake and degradation of acetylated low density lipoprotein, producing massive cholesterol deposition. Proc. Natl. Acad. Sci. USA 76:335-337; 1979.

Grant, A. G.; Billing, B. H. The isolation and characterization of a bile ductule cell population from normal and bile-duct ligated rat livers. Br. J. Exp. Pathol. 58:301-310; 1977. 
Grubman, S. A.; Perrone, R. D.; Lee, D. W., et al. Regulation of intracellular $\mathrm{pH}$ by immortalized human intrahepatic biliary epithelial cell lines. Am. J. Physiol. 266:G1060-G1070; 1994.

Ishii, M.; Vroman, B.; LaRusso, N. Isolation and morphologic characterization of bile duct epithelial cells from normal rat liver. Gastroenterology 97:1236-1247; 1989.

Jacobs, W. L. W. A colorimetric assay for gamma-glutamyltranspeptidase. Clin. Chim. Acta 31:175-179; 1971.

Johnston, D. E.; Marcadis, D.; Corcoran, G. B., et al. Purification of primary human hepatocytes using ricin A chain. In Vitro Cell. Dev. Biol. 32A:388-390; 1996.

Joplin, R.; Stain, A. J.; Neuberger, J. M. Immuno-isolation and culture of biliary epithelial cells from normal human liver. In Vitro Cell. Dev. Biol. 25:1189-1192; 1989.

Joplin, R.; Hishida, T.; Tsubouchi, H., et al. Human intrahepatic biliary epithelial cells proliferate in vitro in response to human hepatocyte growth factor. J. Clin. Invest. 90:1284-1289; 1992.

Linsenmayer, T. F. Collagen. In: Hay, E. D., ed. Cell biology of the extracellular matrix. $2^{\text {nd }}$ ed. New York: Plenum Press; 1991:7-44.

Mathis, G. A.; Walls, S. A.; Sirica, A. E. Biochemical characteristics of hyperplastic rat bile ductular epithelial cells cultured "on top" and "inside" different extracellular matrix substitutes. Cancer Res. 48:6145-6153; 1988

Mathis, G. A.; Sirica, A. E. Effects of medium and substratum conditions on the rates of DNA synthesis in primary cultures of bile ductular epithelial cells. In Vitro Cell. Dev. Biol. 26:113-118; 1990.

Meister, A.; Tate, S. S.; Leonard, R. L. Membrane-bound-gamma-glutamyl transpeptidase. In: Martinosi, A., ed. The enzymes of biological membranes. New York: Plenum Press; 1976:315-347.

Montesano, R.; Matsumoto, K.; Nakamura, T., et al. Identification of a fibroblast-derived epithelial morphogen as hepatocyte growth factor. Cell 67:901-908; 1991a.

Montesano, R.; Schaller, G.; Orci, L. Induction of epithelial tubular morphogenesis in vitro by fibroblast-derived soluble factors. Cell 66:697$711 ; 1991 \mathrm{~b}$

Nerurkar, L. S.; Marino, P. A.; Adams, D. O. Quantification of selected intracellular and secreted hydrolases of macrophages. In: Herskowitz, $\mathrm{H}$. B.; Holden, H. T.; Bellanti, J. A.; Ghaffar, A., ed. Manual of macrophage methodology. New York: Marcel Dekker, Inc.; 1981:229-247.

Okamoto, H.; Ishii, M.; Mano, Y., et al. Confluent monolayers of bile duct epithelial cells with tight junctions. Hepatology 22:153-159; 1995.

Omura, T.; Sato, R. The carbon monoxide-binding pigment of liver microsomes. J. Biol. Chem. 239:2370-2378; 1964.

Paradis, K.; Sharp, H. L. In vitro duct-like structure formation after isolation of the bile ductular cells from a murine model. J. Lab. Clin. Med. 113:689-694; 1989.

Perrone, R. D.; Grubman, S. A.; Rogers, L. C., et al. Continuous epithelial cell lines from ADPKD liver cysts exhibit characteristics of intrahepatic biliary epithelium. Am. J. Physiol. 269:G335-G345; 1995.

Robertson, E. J. Embryo-derived stem cell lines. In: Robertson, E. J., ed. Teratocarcinomas and embryonic stem cells: a practical approach. Oxford, England: IRL Press; 1987:71-112.

Rathjen, P. D.; Toth, S.; Willis, A., et al. Differentiation inhibiting activity is produced in matrix-associated and diffusible forms that are generated by alternate promoter usage. Cell 62:1105-1114; 1990 .
Rhim, J. A.; Sandgren, E. P.; Degen, J. L., et al. Replacement of diseased mouse liver by hepatic cell transplantation. Science 263:1149-1152; 1994.

Rohme, D. Evidence for a relationship between longevity of mammalian species and life spans of normal fibroblasts in vitro and erythrocytes in vivo. Proc. Natl. Acad. Sci. USA 78:5009-5013; 1981.

Rutenberg, A. M.; Kim, H.; Fischbein, J. W., et al. Histochemical and ultrastructural demonstration of gamma-glutamyl transpeptidase activity. J. Histochem. Cytochem. 17:517-526; 1969.

Schmitt, R. M.; Bruyns, E.; Snodgrass, H. R. Hematopoietic development of embryonic stem cells in vitro: cytokine and receptor gene expression. Genes Dev. 5:728-740; 1991.

Singh, A.; Shahidi, E. Ultrastructure of the piglet liver. In: Tumbleson, M. E., ed. Swine in biomedical research. Vol. 1. New York: Plenum Press; 1987:77-87.

Sirica, A. E.; Cihla, H. P. Isolation and partial characterization of oval and hyperplastic bile ductular cell-enriched populations from the livers of carcinogen and noncarcinogen-treated rats. Cancer Res. 44:3454$3466 ; 1984$.

Sirica, A. E.; Sattler, C. A.; Cihla, H. P. Characterization of a primary bile ductular cell culture from the livers of rats during extrahepatic cholestasis. Am. J. Pathol. 120:67-78; 1985.

Sirica, A. E. Biology of biliary epithelial cells. Progress in Liver Diseases 10:63-87; 1992.

Sirica, A. E.; Gainey, T. W. A new rat bile ductular epithelial cell culture model characterized by the appearance of polarized bile ducts in vitro. Hepatology 26:537-549; 1997.

Stoker, M.; Gherardi, E.; Perryman, M., et al. Scatter factor is a fibroblastderived modulator of epithelial cell mobility. Nature 327:239-242; 1987.

Talbot, N. C.; Rexroad, C. E., Jr.; Pursel, V., et al. A continuous culture of pluripotent fetal hepatocytes derived from the 8-d epiblast of the pig. In Vitro Cell. Dev. Biol. 30A:843-850; 1994a.

Talbot, N. C.; Rexroad, C. E., Jr.; Pursel, V., et al. Colony-cloning and secondary culture of fetal porcine hepatocytes on STO feeder cells. In Vitro Cell. Dev. Biol. 30A:851-858; 1994b.

Talbot, N. C.; Paape, M. J. Continuous culture of pig tissue-derived macrophages. Methods Cell Sci. 18:315-327; 1996.

Talbot, N. C.; Pursel, V.; Caperna, T. J., et al. Ultrastructure and enzymatic characteristics of the PICM-19 pluripotent fetal liver cell line. Exp. Cell Res. 225:22-34; 1996.

Tanaka, M. A histochemical study on the activity of gamma-glytamyl transpeptidase in liver disease. Acta Pathol. Jpn. 24:651-665; 1974.

Toole, B. Proteoglycans and hyaluronan in morphogenesis and differentiation. In: Hay, E. D., ed. Cell biology of the extracellular matrix. 2nd ed. New York: Plenum Press; 1991:305-341.

Van Eyken, P.; Desmet, V. J. Bile duct cells. In: LeBouton, A. V., ed. Molecular and cell biology of the liver. Baton Raton, Florida: CRC Press; 1993:475-524.

Vroman, B.; LaRusso, N. F. Development and characterization of polarized primary cultures of rat intrahepatic bile duct epithelial cells. Lab. Invest. 74:303-313; 1996.

Yang, L. I.; Faris, R. A.; Hicks, D. C. Long-term culture and characteristics of normal rat liver bile duct epithelial cells. Gastroenterology 104:840-852; 1993.

Yokoyama, H. O.; Wilson, M. E.; Tsuboi, K. K., et al. Regeneration of mouse liver after partial hepatectomy. Cancer Res. 13:80-85; 1953. 